\title{
The Polity of Regional Integration Development and the Challenges Hampering Southern Africa Economic Growth
}

\author{
Andrew Enaifoghe* \& Sandile Blessing Mkhwanazi \\ Department of Public Administration, University of Zululand, KwaZulu-Natal, South Africa \\ andyransey@gmail.com
}

\begin{abstract}
This paper explored the polity of regional integration development and the challenges hampering the southern Africa economic growth. The study finds that the design and structure of the African regional development within the integration schemes is around inward-looking industrialization that is intended to facilitate economic costs of participation for member states. This often remains unevenly distributed among member states. Most countries in Africa linger highly reliant on agriculture and yet suffer from high levels of unemployment and food insecurity in the continent. In these situations, it is logical for one to expect the "African regional integration in the Southern African Development Community (SADC) sub-regional schemes to be most focused on developing whatsoever synergies that may exist to promote both socio-economic development and regional security across borders, which may hamper the policy implementation through good governance and ethical valued approach. Qualitatively, this paper collected data and analysis them based on content, using secondary sources from different domains, including Google scholars, Scorpius repositories.
\end{abstract}

Keywords: Economic development, continental identity, insecurity, SADC integration.

\section{Introduction}

Africa has the potential to develop its continent by looking at its fastest rate of demographic growth in the world. Africa seems to be at a "crossroads", and the question is whether its growing working population can drive to promote a much-anticipated demographic dividend. There have been several calls to Africa leaders to develop the strategies that promote good governance for both regional and continental development, as it is paramount in the 21st century (Enaifoghe, 2019). The New Partnership for Africa's Development (NEPAD), attempted to chart a new course of good governance and effective development for the continent. Africa development has received many articulations with the need for a broader, emerging and incipient unanimity or agreement on deliberate strategic policies for a long-term economic reawakening. Based on the analyses of every economic management by Africans and non-Africans, Enaifoghe (2019), it is clear that Africa has not been promoting moral ethics in governance to achieve the desired socio-economic development. Africa is caught up in the global ideologies - they often subscribe to the global ideas of development.

Which not directly apply Africa ideology, unless begin to think inward development by adopting afro-global in the pursuit of its socio-political and economic development; the continent will remain an outward global resource system for outsiders. This means that Africa will remain a resource that provides resources including the human capacity to develop other regions. Afroglobal is a system where individual, group or organization can appreciates or subscribe to foreign ideologies but apply that idea to the local or immediate environment. In 2010 the McKinsey Global Institute (MGI) described the probable and the development growth of African economies as "lions on the move" (World Economic Forum, 2016: 6). Despite the breakdown of global service prices and political shocks that have slowed growth in North Africa, Africa's economic lions are still moving forward (Leke and Barton, 2016). This article assesses the extent to which Africa countries have improved concerning the various calls and the target set by a different international organisation on the African development process.

\section{Methodology}

This study is qualitative research which used secondary resource content data analysis method, this method allows researchers to study, and thereby making sense of written documents, which may be available either in the public or private domain (Mogalakwe, 2006). This means that the researcher determines the relevance of the documents that they consult based on their significance to the study. Qualitatively, data were collected primarily through secondary sources, which include, the Internet sources, books, reports, periodicals, policy 
briefs, journal, articles, news bulletins and official documents on the African integration agenda as well as the Southern African sub-regional integration implementation.

\section{Literature Review Consideration}

Over 100 literature were sourced in the different domain using advanced searches from Google scholars and Scorpius on the subject. The collected data were analysed based on content and relevance, but only 40 literature were used that were found relevant to inform the study. The African continent has overall achieved average real annual GDP growth of 5.4\% between 2000 and 2016, adding $\$ 78$ billion annually to GDP (in 2015 prices). The growth slowed to $\$ 69$ billion (3.3\%), a year between 2010 and 2015 (Leke and Barton, 2016). The question is, has the glory come off Africa's growth story? Though the new research from the MGI answered the above as no, it is clear that the continent's growth story has become a more nuanced one (Leke and Barton, 2016). In line with this, foremost global conferences and dialogues have called on individual countries not only to prepare but as to implement the "National Strategies for Sustainable Development" (NSSD). The launch of "regional economic blocs not only strengthens member countries' positions on the global political landscape and bargaining power on international issues but also enables countries to collectively grapple with the region's economic progress" (Enaifoghe \& Adetiba, 2018). Matthews (2003) thought, "Individual countries within any given economic bloc cannot deal with the economic challenges single-handedly; hence the mooting of the idea of regional economic integration". Chingono \& Nakana (2008) state, that regional integration has become increasingly accepted as an essential key component in facilitating both economic and political development. Considering the African experience of regional integration schemes in sub-Saharan Africa, the regionalism in Africa has always had a strong political motive.

However, the call for Pan-Africanism is the manifestation of "continental identity and coherence, distinguishes regional integration in Africa from other regions in the developing world" (McCarthy, 1995). Nevertheless, the usual economic arguments often put forward for "regional co-operation" are "particularly strong given the small size of many sub-Saharan Africa countries in economic terms". Furthermore, the report of the FAO (2003) saw most African countries to have remained highly dependent on agriculture and suffered from high levels of both social, political and economic insecurity in the continent. In these situations, one would expect that the "African regional integration schemes" to be focused on developing whatsoever synergies that may exist within the region (Matthews 2003); to promote both social, political and economic development. After the wave of independence that flounced the African continent in the 1960s and beyond, integration arrangements had increasingly become a significant contrivance for smoothing and promoting "economic growth and development in the then recently decolonised African economies" (SAHO, 2015: 1). The African development agenda was pioneered by some African visionary leaders in the likes of Ghana's Kwame Nkrumah who advocated for full "continental integration" which he saw as a necessary means to guarantee that Africa is taken seriously "on the world stage, especially as it prepared to take its place as an independent actor in the global economy" (SAHO, 2015: 1). Integration was regarded vital to address and streamline the "skewed neo-colonial relationships and trading practices" which according to Abraham (2008) had in the "past, maintained Africa's overreliance on primary commodity exports".

The above perception was the central motivation for the setting up of the "Organisation of African Unity (OAU) in 1963, Spartan restrictions and Constraints within the OAU also meant that it was only about being able to fulfil its primary mission to ensure liberation on the continent before it was disbanded and replaced by the African Union in 2002" (SAHO, 2015). The Organization of African Unity (OAU) made few major moves towards "the goal of regional economic integration in 1991". The organisation embraced the "Treaty Establishing the African Economic Community (AEC), also known as the Abuja Treaty", which was aimed at primarily promoting the continental unity of all African nations through a harmonised "economic and security policies within Africa's regional economic communities" (RECs) (Enaifoghe, 2019). Nevertheless, the Abuja Treaty was embraced by the new organisation after dissolving the OAU to establish the new 'African Union (AU)', which then deliberated the "regional economic integration' to be a flagship project in driving African political and economic development". According to the AU organisation, they consider (Enaifoghe \& Asuelimen, 2018). Regional integration as the process where two or more countries in a particular area voluntarily join together to pursue common policies and objectives in matters of general economic development or a particular economic field of common interest to the mutual advantage how is a mutual 
advantage" (Enaifoghe \& Asuelimen, 2018). The question is in which form would they also be any form of documents that these countries have to sign to state their agreements and benefits? How does it work for all the partaking States? The Abuja Treaty, on regional and economic integration is envisaged to be realised in stages as follows:

Stage 1: creating new RECs (Regional Economic Commission) and strengthening existing RECs (by 1999).

Stage 2: stabilizing barriers to regional trade (by 2007).

Stage 3: establishing a free-trade area (FTA) and a customs union for each REC (by 2017).

Stage 4: coordinating tariff and non-tariff systems among RECs (by 2019).

Stage 5: establishing an African Common Market and common policies among RECs (by 2023).

Stage 6: establishing an African Central Bank, creating a continental monetary union and electing the first PanAfrican Parliament (by 2028) (Asante, 1997).

The Abuja Treaty framework provided the existence of eight "Regional Economic Communities (RECs) in Africa's five sub-regions; the Arab Maghreb Union (AMU), the Common Market for Eastern and Southern Africa (COMESA), the Community of Sahel-Saharan States (CEN-SAD). The East African Community (EAC), the Economic Community of Central African States (ECCAS), the Economic Community of West African States (ECOWAS), the Inter-governmental Authority on Development (IGAD) and the Southern African Development Community (SADC)" (Asante, 1997: 37). Furthermore, with the Abuja Treaty, the new regional organisation (AU) in 2001 adopted the New Partnership for Africa's Development (NEPAD), which was invented and not innovative by former South African President Thabo Mbeki, whose aim was to "reposition Africa in the global stage, eradicate poverty and placing Africa on the road to sustainable development" (United Nations Department of Economic and Social Affairs Division for Sustainable Development (2011). In line with the former President's Mbeki's vision, NEPAD provided a framework which underpinned the imperative role, that is to be played by the aforementioned Regional Economic Commissions' effort to address development and integration challenges issues incontinent. Equally the RECs are reflected as the primary proxies voted to implement the NEPAD's agendas and plans. Furthermore, NEPAD emphasises the position of African "ownership and leadership, based on a neo-liberal framework" which therefore encourages "privatisation, liberalisation and deregulation".

More so, the NEPAD commission strives for economic development through the pull of foreign direct investment (FDI) from highly developed nations around the world (UNCTAD, 2019)). In ensuring the effective running of the NEPAD, the African Union institution is to act as the principal vehicle for the development of regional integration in Africa, it was expected to promote Africa's integration into the international economy. However, according to Gibb (2009), the success in this undertaking has been "slow and marred by delay and stagnation". Enaifoghe \& Adetiba (2018), noted that certain "RECs have made progress in some priority areas such as the establishment of FTas in ECOWAS, ECCAS, COMESA and the EAC, and the launch of customs unions in the EAC and COMESA, the benefits of integration have not been achieved as timeously as was intended". In that regards, there are quite a number of elucidations as to why Africa has had misfortune in integrating the continent economically. These factors or setbacks range from the confidence or acceptance that the "inherited structures of the AU subject the institution to the limitations of its predecessor" (UNCTAD, 2020; SAHO (2015: 1). This is in the form of established weakness and (Enaifoghe \& Asuelime, 2018), shortages in resources, and the lack of "political will on the part of REC member States" to want to relinquish some level of control of their State sovereignty to a regional body like the African Union. Just as it was within the European Union (EU) during the integration of Europe, which is seen as one of the best in the world (Enaifoghe \& Asuelime, 2018).

Africa's Regional Integration Efforts in Promoting Economic Development: Since independence, several attempts has been made to industrialize efficiently, using import-substitution have failed, giving rise to the concept of regional integration as a way of promoting systemic change in Africa. As a result, most African countries have embraced regional integration as a crucial aspect of their sustainable development, driven mainly by overarching framework for addressing the limitation of small and rotational economies operating in isolation. (United Nations, 2018). Numerous pan-African organizations have worked sequentially to establish and advance economic, social and political cooperation and integration of the continent. Several colonial cross-border agreements have remained in place since independence and have served the regional integration agenda. The ECA (2018a) noted several prime examples relating to "the previous 'African 
Financial Community (CFA) zone, consisting of the West African CFA franc and the Central African CFA franc.' Other realistic examples include the West African CFA franc, which was eventually incorporated into the West African Economic and Monetary Union (WAEMU) in the territory of ECOWAS". According to the United Nations Economic Commission for Africa (2018), the "Central African CFA franc is set to join the Economic and Monetary Union of Central Africa (CEMAC) in the ECCAS region" (ECA, 2018a). Similarly, in Southern Africa, the Southern African Customs Union (SACU) and its related monetary union, there is a shared currency region to be incorporated into the SADC electoral district.

However, the sub-region is yet to achieve this agenda of single currency implementation. Nevertheless, in line with the regional integration proceedings on the continent, there are "various pan-African organizations, which are through different mechanisms established to promote sustainable economic growth and development in the continent, where the key factor of regional integration is present in their workings". The ECA is such that was established by "the Economic and Social Council of the United Nations in 1958 as one of the five regional commissions of the United Nations that, together with partners and member States, consecutively work towards sustainable development in Africa" (United Nations, 2018). The economic commission for Africa is meant to provide technical assistance by conducting research and policy analysis to improve the capacity of regional integration institutions, including the African Union, regional economic communities and the Member States. (ECA, 2018b). The ECA (2018b), states that the key priority of ECA is to target "Africa's development challenges, particularly in the context of poverty eradication, to ensure sustainable growth and good governance on the continent and thus promote international cooperation for Africa's development". The commission has since the 1960s, recommended "the creation of sub-regional groupings in Africa to serve that purpose".

Just about the same time, UNECA (2017), noted that the "Heads of State and Government of 30 of the 32 independent African nations gathered to establish. The Organization of African Unity (OAU) at the Conference of Independent African States on 25 May 1963". Matthews (2003) articulated that apart from the liberalization efforts of colonization and apartheid, the main objectives of OAU were: to promote unity and solidarity among the African States; to organize and strengthen cooperation for development on the continent; to protect the sovereignty and territorial integrity of its member states, and to encourage international cooperation as outlined by the United Nations. The establishment of the African Development Bank Group (AfDB) was parallel to the formation of the OAU. It was founded following an agreement signed by 23 founding Member States on 14 August 1963 in Khartoum, Sudan (UN 2018). The Group comprises two other bodies, "with AfDB as the parent organization - the African Development Fund, which was set up on 29 November 1972 by the AfDB and 13 non-African countries; and the Nigeria Trust Fund, which was set up in 1976 by the Federal Government of Nigeria" (UN 2018). The African Development Bank (AfDB) Group was set up as a "financial institution" to respond to the need for enhanced cooperation on public and private capital investment in projects likely to contribute to the economic and social development of the continent.

\section{SADC Economic Development and the Challenges Hampering Integration}

Discussing regional integration in Africa is a complex topic and extremely difficult, and this difficulty and complexity have led to disagreements, frustration and confusion (Thonke \& Spliid, 2012). The complexity and difficulty of regional integration in the African context can be partly traced to colonisation, which Africa underwent; and the adoption of colonial partitioning of African borders. This was largely made by colonists and the lack of ethical practices in governance and high levels of corruption among African leaders. This, therefore, raises a need to complete a decolonisation agenda by redrawing the African political map (Moyo, 2018). Further, the need is raised to recognise the contexts which African regions face, which are different from other regions in the world although there are similarities. Oloruntoba (2018) argue that the maintenance of colonial borders thwarts human mobility, therefore thus thwarts the objectives of regional integration. The partitioning of Africa borders at the Berlin Conference; and the subsequent maintenance of them by post-independence African governments have thwarted human mobility. Hence it can be deduced that the development of adequate infrastructure across the continent should be of paramount importance to cater. 
To or accommodate human mobility across the borders has been limited (Enaifoghe, 2019). This means that the complete improvement of its infrastructure should be facilitated by the end of 2020 , as it will improve the economy in Africa, and apart from infrastructural development, other matters and resources that need to be improved. However, in the meantime more than concentrating on human mobility and African borders to improve the economy while establishing policies and infrastructure for African borders, include technology advancement and well-developed open market. Braude (2012), noted that the "current pace of globalization gives no choice to small developing countries: they must integrate into world markets if they wish to succeed because Africa has more than its fair share of small poor economies as a result of fragmentation that it inherited from European colonizers". This making Africa the continent most prone to ethnic-based conflicts, yet, African countries impose the heaviest artificial barriers around their borders on top of this. It's time to change this. Africa can adopt a Sub-continental approach, Coulibaly (2017), highlighted that except for the two dominant economies, which are South Africa and Nigeria- the continent is made up of countries with small domestic markets.

Restricted economic diversification and generally low connectivity to neighbouring countries. Reduced Proximity between economic operators within Africa and across Africa and the rest of the world (Coulibaly, 2017). The response of the international community (specifically advanced economies and multinational corporations) to assistance to Africa has so far been essentially country-specific and globalising regional fires: genocides, pandemics, religious wars, etc. - Coulibaly (2017). This method has merit, but a continent chronically suffering from the triple disadvantages of low economic density, long-distance to markets, and deep divisions require a different strategy. This research suggests that it will benefit greatly from a regional strategy, as argued in the 2009 World Development Report. One way to do this is by providing preferential access to the region to the world's leading markets, as provided for by the African Development Potential Act (AGOA) and All But Weapons (EBA), two preferential agreements extended by the United States and the European Union, respectfully, since 2001 (Coulibaly, 2017). However, it is clear that not all African countries, including West African countries, have benefited from this access. Surprisingly, West Africa is home to two of the most advanced regional economic cultures.

The West African Economic and Monetary Union (WAEMU) shares a shared monetary policy that has kept inflation low and is a customs. Union with a compensation mechanism to maintain the Common External Tariff (Coulibaly, 2017). The Economic Community of West African States (ECOWAS) maintains a regional military force and exerts peer pressure that has forced out military coups in its member countries. Oloruntoba (2018) thus assert that intra-African trade has been severely affected by poor infrastructure, trading with outside countries and outward-looking trade policy. The author concludes that two regions in Africa, namely ECOWAS and SADC has made progress in developing infrastructure, in the form of constructing roads across their regions, although such progress is inadequate. African trade is less than $2 \%$ of the total global trade, and that $2 \%$ constitutes about half of the GDP in most African countries (Geda \& Seid, 2015). This is in agreement with the statement by Rekiso (2017) in that African markets are small and fragmented. Further, the colonial legacy, which prohibited colonised States from industrialisation and developing manufacturing sector proves to be one of the major impediments for regional integration in Africa.

When colonisation ended, most African States were dependent on agriculture and mining, and they were largely characterised by low levels of education for the masses, poor infrastructure and poor technical change; and largely intrusive policy frameworks and structures (Rekiso, 2017). From the regional integration perspective, this implies that most of the African economies rely on exporting natural resources and agricultural products, and this implies that development and manufacturing are very limited in Africa. As African economies specialise in exporting raw materials, Rekiso (2017) argue that capitalising on raw materials is tantamount to specialising in poverty, outdated economic models which produce no formal employment opportunities. The author then concludes that technological advancement in the absence of manufacturing sector will push down the export prices, which will then lower the living standards in the raw material dependent economy. This further implies that African markets will remain small, even though regions integrate. There is also a general perception that the African States do not have clearly defined trade interests. The multiplicity of these trade interests makes full integration a difficult endeavour to implement. Geda and Seid (2015) posit that 35\% of the African population from one-thirds of African economies are 
landlocked, therefore their trade and development is largely dependent on the goodwill of their coastal neighbours.

Further, most African States are small and have limited prospects to bargain independently on the international stage. Being a landlocked economy correlates with more costs. When it comes to bilateral trade as there are higher logistics costs to be incurred to access the sea (Geda \& Seid, 2015). Geda and Seid (2015) conclude by stating that transport costs in Africa are 65\% higher than in developed countries, considering that $35 \%$ of the African population is in landlocked countries in contrast with the average of about $1 \%$ globally. The deduction can be made that for African landlocked countries to minimise the effects of being landlocked and improve their socio-economic development, regional integration must be pursued vigorously, and this will serve to minimise relative remoteness of landlocked countries to world markets. Kayizzi-Mugerwa, Anyanwu, and Conceição (2014) opine that being landlocked correlates with being relatively remote from international markets. Further, this would enable African countries to bargain as a region in the global markets and this would greatly benefit African economies (Muzee \& Enaifoghe, 2019). Thonke \& Spliid (2012) state that regional integration would create new and bigger markets in Africa, which would increase capital inflow. Increased capital inflow would increase investments and increase the competitiveness of trade, and later improved socio-economic benefits.

Although African economies are small, and some economies relatively remote from international markets. African countries still largely trade and depend on developed countries for the supply of manufactured goods (Geda \& Seid, 2015). This is partly due to a failure to industrialise and liberalisation of trade that began in the 70 s which was forced by global financial institutions and found most African countries dominantly dependent on agriculture which implied that African fragile manufacturing sector was to face competition from developed countries, thus forcing most African economies to rely on agriculture as a comparative advantage (Rekiso, 2017). Although Africa faces poverty, African states need to develop manufacturing sector as it involves all the features of the economic sector and serves as learning apparatus for the economy through the diffusion of technological progress and its capacity to produce inputs for other sectors in the economy. Rekiso (2017), argued that there is no empirical evidence of the economy that developed without manufacturing or industrial base. However, as the world is moving from industrialization to a more technological advanced revolution, for Africa to move with the trend and remain competitive, it has to try and bridge some of the economic frontiers and in the current $4^{\text {th }}$ industrial revolution (4IR). This will help further prepare for the $5^{\text {th }}$ industrial revolution and move with the train of technological advancement. Apart from the smallness of African markets, there is a general perception that African Stock Markets may be segmented from global stock markets and this perception is usually attributed to political instability, investment barriers, weak accounting standards and information asymmetries that have plagued many African countries (Boamah, Watts, \& Loudon, 2016).

This further makes it more challenging to integrate African stock markets to achieve full regional integration. Further, the unwillingness of African governments to cede macroeconomic sovereignty to a regional body; unwillingness to face high costs that may arise due to importing from a high-cost member state; and unwillingness to discontinue existing relations with non-member state impede both economic and regional integration (Geda \& Seid, 2015). For regions to benefit from their stock markets, there is a need to harmonise their stock market policies to reduce fragmentation and improve accounting standards and information symmetry, unfortunately, this is currently not happening in the SADC countries. Africa faces the challenge of poverty, which is directly linked to colonialism and failure for African economies to industrialise after independence. This then leads to a challenge whereby African RECs depend on international donors for funding and technical assistance, especially those from the West and Europe; and this hinder integration as donor bodies have their demands and criteria (Bilal, Byiers, \& Vanheukelom, 2015). Rekiso (2017) assert that regional integration has implications and effects that come with it; in that, the production of certain exports would shift from one Member State to another, from a high-cost member to a low-cost member, therefore trade will be created; and product origins will shift from a high-cost member to a low-cost member, which will create trade diversion. Scholars argue that trade creation will improve the welfare of the members, while trade diversion can reduce the welfare of the members (Muzee \& Enaifoghe, 2019). But an argument can be made that trade diversion will develop new markets where they did not exist before and allow innovation which will contribute to trade and further allow the opening of new markets. 
For African regional integration to ensure more inclusive socio-economic development, it needs to be, peopledriven. Moyo (2018) laments on how African regional integration mechanisms marginalise non-state actors, with a specific reference to informal cross-border traders, as regional integration is driven by elites. The exclusion of non-state actors can be observed from regional policies, in that the SADC Protocol on Trade excludes cross-border traders, even though informal cross-border traders do move goods and services across borders and integrate economic activities, although informally (Moyo, 2018). Oloruntoba (2018) posit that if activities of the informal cross-border trading were factored in, one would get a different picture of intraAfrican trade; hence there is a need to rethink theories, policies and programmes and governance approaches to regional integration. The author further state that activities by the informal cross-border traders do contribute to poverty alleviation, despite being pushed to the margins (Oloruntoba, 2018). Jordaan (2014) posit that other scholars have a different perspective on regional integration, as they differentiate it into policy-induced integration and market-induced regional integration. The former was driven by policymakers while the latter is driven by the private sector. Empirical evidence shows that for a region to integrate more properly, it is more preferable to integrate through the markets then later through the policies. This can be linked to the argument by Moyo (2018), that African states tend to marginalise non-state actors, especially informal cross-border traders as they are made invisible by policies relating to regional integration; even though they integrate economic activities informally. Further, Jordaan (2014) asserts that Africa's progress on regional integration is further slowed by lack of support from the private sector and the nonimplementation of liberalisation schedules.

Security Challenges Hampering Regional Integration: Africa has multiple security threats that can be solved through regional integration, as regional integration will develop early warning systems and instruments to deal with security threats in African regions (Wachira, 2003). West Africa as a region is faced with security threats in a form of organised cross-border criminal networks. This is amplified by the proliferation of small arms and light weapons, which is linked to civil wars, conflicts and Boko Haram terrorism (Okeke \& Odubajo, 2018). The authors state that although West Africa is faced with security threats, it has one of the most sophisticated peace and security arrangements. The SADC region differs from other regions in Africa in that some of the States were settled by colonialists and established white supremacist rule in Rhodesia (today Zimbabwe), Namibia and South Africa. It made it a unique region, with a different power configuration compared to other regions in Africa. This led to the history of the Southern African region being dominated by destabilising attempts by South Africa as it aimed to preserve white minority rule. The other countries in the region resisted the destabilising forces by South Africa and assisted the helping hand to liberation movements from both South Africa and Zimbabwe. Further, South Africa's destabilising tactics in the region cost an estimated $\$ 62.42$ billion and more than half a million fatalities, and this legacy will always be a mark when it comes to integrating the region. South Africa provided military and other forms of assistance to rebel forces in Angola and Mozambique which further destabilise the region.

States in Southern Africa formed Southern Africa Development Coordinating Conference (SADCC) in 1980 to counter apartheid, South Africa. When Zimbabwe obtained independence in 1980 it also joined, so did Namibia in 1991. Anti-apartheid movements namely the ANC and PAC were observers in the SADCC. The formation of the SADCC greatly diminished the power by apartheid South Africa to destabilise the region (Okeke \& Odubajo, 2018). It is from this history that the SADC emerged, and this history will be a major factor of the region for some time. The destabilising tactics by apartheid South Africa did hinder economic development in the region and did push some economies to the margins. Okeke and Odubajo (2018) posit that the political changes of the 1990s globally, as well as the transition of South Africa towards a majority rule, changed the arrangements of SADCC into Southern Africa Development Community. Further, 1994 marked the change in SADC as South Africa became democratic and joined SADC. Further, it changed its foreign policy stance, thus the security dynamics of the region changed considerably. The change in the security dynamics does not imply that the region is spared from security threats; the region still has security threats to contend with, albeit not military. SADC is faced with the challenges of human security that emanate from illegal migration, the prevalence of HIV/AIDS, cross-border criminal activities, human trafficking, piracy on the seas, poverty and political instability (Okeke \& Odubajo, 2018). Security challenges that SADC face affects all member states, albeit unequally. They further hamper development and economic growth as they are leaks to the financial resources that can be invested to develop the economies in the region. 


\section{Conclusions and Recommendations}

In conclusion, Africa has the potential to develop its continent looking at its fastest rate of demographic growth in the world. The call for African Development and good governance strategies for both regional and continental development is truly paramount in the 21st century as stated above. This article assessed African development concerning the various calls and the target set by a different international organisation on the African development process. While most countries are increasingly smearing the principles of "multistakeholder participation and ownership, sound leadership and good administration of governance, ethics and value in all aspect of governance, the progressively, ministries accountable for states planning and finance have subsequently played key roles in the NSSD course of development. Africa should create a strategic development planning processes that will provide the socio-economic support require to foster development in the continent through the integration of Africa continentally. The Southern African subregion has an environment that is "ideal for interstate trade and forging of economic links" between members.

It further discussed the economic challenges the SADC regional grouping has encountered in its effort to nurture a sub-regional integration, by engaging in the debate around the importance of regional integration and the reasons behind the challenges. There are numerous reasons for the past lack of success of African regional groupings, and of course few successes. This article, therefore, recommends the need for African states to recognise the capacity of the private sector to generate wealth and induce development, and to recognise the capacity of the informal sector as an absorber to extreme poverty. This recognition will improve the socio-economic status and induce more intra-regional trade and more so foster development. For regional integration to be transformative, it requires States to be at similar levels of economic development, therefore, it will be beneficial to member States. Further, States need to have a solid industrial base to ensure healthy regional integration. For economic regional integration to function, countries need to be on a similar level of economic development and industrialisation, this can be achieved through open market and trade integration among members.

\section{References}

Abraham, K. (2008). The Challenges of Accelerating Economic and Political Integration in the Formation of a Union Government, in Murithi, T. (Ed). Towards a Union Government for Africa: Challenges and Opportunities. Pretoria: Institute for Security Studies, 29-43.

Asante, S. K. B. (1997). Regionalization and Africa's Development: Expectations, Reality and Challenges. London: Macmillan.

Bilal, S. A. N., Byiers, B. \& Vanheukelom, J. A. N. (2015). Political-economy dynamics check format matter most to Africa's regional integration. International Trade Forum, (2), 20-21.

Boamah, N. A., Watts, E. J. \& Loudon, G. (2016). Investigating temporal variation in the global and regional integration of African stock markets. Journal of Multinational Financial Management, 36, 103-118.

Braude, W. (2012). SADC, COMESA and the EAC: Conflicting regional and trade agendas, Institute for global Dialogue Occasional Paper No 57 (2008). Available at http://www.acp-eutrade.org/library/files/Jakobeit-Hartzenberg-Charalambides_05_Overlapping-membership.pdf (accessed 10 May 2012).

Chingono, M. \& Nakana, S. (2008). The challenges of regional integration in Southern Africa (2008), African Journal of Political Science and International Relations, 10(3), 396-408.

Coulibaly, S. (2017). Six steps to start changing how Africa does development. Brookings. Wednesday, July 19, 2017.

ECA. (2018a). Overview ECA Overview From ideas to actions for a better Africa. United Nations Economic Commission for Africa

ECA. (2018b). Key Pillars of Africa's Regional Integration. United Nations Economic Commission for Africa

Enaifoghe, A. O. \& Adetiba, T. C. (2018). South African Economic Development and the SADC Sub regional Integration, Journal of Economics and Behavioural Studies (JEBS), 10(1), 135-145.

Enaifoghe, A. O. \& Asuelime, R. (2018). South Africa's National Development vis-à-vis Regional Dynamics. Journal of African Foreign Affairs (JoAFA), 5(1), 129-147 
Enaifoghe, A. O. (2019). South Africa's Politics of Regional Integration in SADC and its Socio-Economic Implications. Journal of African Foreign Affairs (JoAFA), 6(1).

FAO. (2003). Agricultural Development Policy: Concepts and Experiences, Roger D. Norton, Rome

Geda, A. \& Seid, E. H. (2015). The potential for internal trade and regional integration in Africa. Journal of African Trade, 2(1-2), 19-50.

Gibb, R. (2009). Regional Integration and Africa's Developmental Trajectory: Meta-Theories, Expectations and Reality. Third World Quarterly, 30(4), 701-721.34

Jordaan, A. C. (2014). Regional integration in Africa versus higher levels of intra-Africa trade. Development Southern Africa, 31(3), 515-534.

Kayizzi-Mugerwa, S., Anyanwu, J. C. \& Conceição, P. (2014). Regional Integration in Africa: An Introduction. African Development Review, 26, 1-6.

Leke, A. \& Barton, D. (2016). 3 reasons things are looking up for African economies. 05 May, 2016

Matthews, A. (2003). Regional Integration and Food Security in Developing Countries. Food and Agriculture Organization of the United Nations Rome, 2003

McCarthy, C. (1995). Regional integration: part of the solution or part of the problem? In Ellis, S. ed., Africa Now: People, Policies, and Institutions. London, James Currey/Portsmouth, Heinemann.

Mogalakwe, M. (2006). Research Report. The Use of Documentary Research Methods in Social Research. African Sociological Review, 10(1), 221-230.

Moyo, I. (2018). Theorizing Borders in Africa: What are the Implications for African Integration? Africa Insight, 48(1), 29.

Muzee, H. \& Enaifoghe, A. O. (2019). Towards an Inclusive Model of African Regional Integration: How effective has the Linear Model been so far? Journal of Economics and Behavioral Studies (JEBS), 11(1).

Okeke, G. S. M. \& Odubajo, T. (2018). Regional Economic Groupings and Security Challenges: A Comparative Study of ECOWAS and SADC. Journal of International \& Global Studies, 9(2), 111-126.

Oloruntoba, S. O. (2018). Regional Integration and Development in Africa: Rethinking Borders and Informality. Africa Insight, 48(1), 12.

Rekiso, Z. S. (2017). Rethinking regional economic integration in Africa as if industrialization mattered. Structural Change and Economic Dynamics, 43, 87-98.

SAHO. (2015). The African Union and Regional Economic Integration. Produced 30 October 2015 Last Updated 27 August 2019

Thonke, 0. \& Spliid, A. (2012). What to expect from regional integration in Africa. African Security Review, 21(1), 42-66.

UNCTAD. (2019). Foreign direct investment to Africa defies global slump, rises $11 \%$

UNCTAD. (2020). Investment flows in Africa set to fall sharply, says new UNCTAD report From Africa Renewal: June 2020

UNECA. (2017). Available: http://www.uneca.org/pages/overview

United Nations Department of Economic and Social Affairs Division for Sustainable Development. (2011). Sustainable Development in the 21st century (SD21) Review of implementation of Agenda 21 and the Rio Principles. December 2011, DRAFT

United Nations. (2018). History of Africa's Regional Integration Efforts. United Nations Economic Commission for Africa.

Wachira, G. (2003). Linking Peace, Security and Regional Integration in Africa. United Kingdom, Europe.

World Economic Forum, World Bank. \& African Development Bank. (2011). The Africa Competitiveness Report 2011. (WEF, WB, ADB). 